\title{
Associative and non-associative learning shapes mixture representation and improves perception of relevant odors
}

\author{
Fernando Locatelli", Emiliano Marachlian \\ From 1st International Workshop on Odor Spaces \\ Hannover, Germany. 4-7 September 2013
}

Animals live in a world of countless olfactory stimuli that are normally presented forming complex and variable mixtures. To deal with excess of information they should have systems that process the sensory afference and optimize detection of the relevant odors. In case of specialist animals, whose success depends on detection of defined molecules, this optimization is hardwired or solved by specific olfactory receptors. In the present work we asked if detection of relevant odors can be optimized when the category "relevant or irrelevant" is not fixed but depends on the experience of each individual with odors and rewards. Honey bees provide a good model for this study, because their foraging behavior depends on generalist olfactory receptors and because they are able to learn the predictive value of originally neutral odors. Olfactory stimuli to which bees are normally exposed are complex mixtures, in which relevant odors can be masked by the presence of irrelevant ones. The meaning and significance of odors may change and bees have to keep their olfactory sense adjusted to these changes. We performed calcium imaging in projections neurons of the honey bee antennal lobe and measured the neural representation of mixtures and the pure components after associative and non-associative learning. On the basis of patterns obtained for naïve animals we assayed different algorithms that allow accurate prediction of the pattern elicited by the mixture. The prediction algorithms were later applied to animals that have been trained on appetitive conditioning using as conditioned stimulus one of the components of the mixture. We found that the representation of the mixture in trained animals deviates from the mixture predicted for naïve animals. This deviation is

Laboratorio de Neurobiología de la Memoria, Facultad de Ciencias Exactas y Naturales, Universidad de Buenos Aires. IFIByNE- CONICET. Argentina in favor of the representation of the rewarded component. The changes in the mixture seem to be consequence of changes in the interactions among components since normally no change was observed in the representation of pure odors. The results are consistent with a model in which plasticity the antennal lobe can redefine the perceptual space according to experience and needs.

\section{Acknowledgements}

Participation to this meeting was supported by an ECRO Travel Grant.

Published: 16 April 2014

doi:10.1186/2044-7248-3-S1-P8

Cite this article as: Locatelli and Marachlian: Associative and nonassociative learning shapes mixture representation and improves perception of relevant odors. Flavour 2014 3(Suppl 1):P8.
Submit your next manuscript to BioMed Central and take full advantage of:

- Convenient online submission

- Thorough peer review

- No space constraints or color figure charges

- Immediate publication on acceptance

- Inclusion in PubMed, CAS, Scopus and Google Scholar

- Research which is freely available for redistribution

Submit your manuscript at www.biomedcentral.com/submit
() Biomed Central 